\title{
Colgajo de SMAS en la prevención del síndrome de Frey
}

\author{
SMAS flap for the prevention of Frey's syndrome
}

\author{
C. Moreno García', H. Serrano Gil', F. Monje Gil'2, C. Pérez Herrero3, A.J. Morillo Sánchez³, \\ J. Mateo Arias', J.C. Moreno Vázquez³, L. Ruiz Laza3
}

Resumen: Objetivo. El síndrome de Frey puede surgir como complicación tras cirugía de la glándula parótida. Este artículo pretende analizar la prevención de dicho síndrome tras cirugía parotídea cuando se realiza la elevación de un colgajo de sistema músculo aponeurótico superficial (SMAS). Material y Método. Presentamos un estudio retrospectivo con 81 pacientes a los que se realizó cirugía sobre la glándula parótida, en el Servicio de Cirugía Oral y Maxilofacial del Hospital Infanta Cristina de Badajoz desde Octubre de 1997 hasta Febrero de 2005.

Resultados. La técnica más comúnmente realizada en nuestro Servicio fue la parotidectomía superficial conservadora (68\%). El grupo más numeroso lo formaron aquellos pacientes en los que se realizó colgajo de SMAS y no desarrollaron posteriormente síndrome de Frey con un total de 56 casos (69\%).

Conclusión. Consideramos adecuada la realización de colgajo de SMAS en cirugía parotídea, para disminuir la frecuencia de aparición del síndrome de Frey.

Palabras clave: Síndrome de Frey; Colgajo de SMAS; Prevención.

\begin{abstract}
Objective. Frey's syndrome may occur as a complication following parotid gland surgery. The aim of this article is to analyze the prevention of this syndrome after parotid surgery during which a superficial musculoaponeurotic system (SMAS) flap is elevated.

Material and Methods. A retrospective study is presented of 81 patients who underwent parotid gland surgery in the department of Oral and Maxillofacial Surgery of the Hospital Infanta Cristina, Badajoz, from October 1997 to February 2005.

Results. The most common technique used in our department was the superficial conservative parotidectomy (68\%). The most numerous group was made up of patients with SMAS flaps who did not go on to develop Frey's syndrome, with a total of 56 cases (69\%). Conclusion. We consider carrying out a SMAS flap in parotid surgery appropriate for reducing the frequency with which Frey's syndrome appears.
\end{abstract}

Key words: Frey's syndrome; SMAS flap; Prevention.

Recibido: 07.07.2005

Aceptado: 04.07.2006

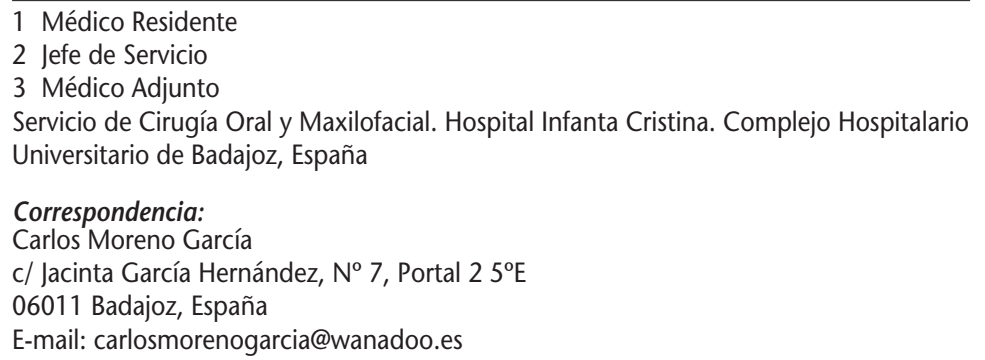




\section{Introducción}

El síndrome de Frey, ${ }^{1}$ también denominado síndrome del nervio auriculotemporal o de la sudoración gustatoria, se caracteriza por la aparición de eritema y sudoración en la piel de la cara, normalmente en la región preauricular, en relación con la masticación y la deglución. Se ha observado en pacientes tras sufrir una parotidectomía, herpes zoster trigeminal, parotiditis, fracturas de cóndilo mandibular, traumatismos obstétricos con fórceps y cirugía del meningioma del ángulo pontocerebeloso. ${ }^{2}$

Tras la cirugía de glándula parótida su frecuencia oscila entre $30-60 \%$. $^{3}$ Se describe como una complicación tardía que suele aparecer a partir de los 36 meses tras la intervención quirúrgica. $^{3}$

El objetivo del presente artículo es analizar si es posible prevenir la aparición del síndrome de Frey tras preservación y realización de colgajo de SMAS en la cirugía de glándula parótida.

\section{Material y Método}

Hemos realizado un estudio retrospectivo que incluye 81 casos de cirugía sobre glándula parótida realizados en el Servicio de Cirugía Oral y Maxilofacial del Hospital Infanta Cristina de Badajoz entre Octubre de 1997 y Febrero de 2005.

Para el diagnóstico del síndrome de Frey además de la clínica hemos utilizado el test de Minor. Consiste en aplicar yodo en la piel, dejar que seque, añadir una capa de almidón y ofrecer al paciente algún sialogogo, que estimulará la sudoración. Todo esto hará que el almidón se mezcle con el yodo cambiando a una coloración oscura concluyente. ${ }^{2,4}$

La técnica quirúrgica del SMAS fue la siguiente: Tras la elevación de colgajo de piel y tejido celular subcutáneo, se disecciona el SMAS de la fascia parotídea (Fig. 1). La disección ha de ser muy cuidadosa a medida que avanzamos en un plano más anterior, para no lesionar las ramas del nervio facial subyacente a la fascia. El límite quirúrgico se sitúa un centímetro por debajo del arco cigomático y el límite inferior no debe sobrepasar más de un centímetro del borde mandibular. Tras realizar la parotidectomía se coloca un drenaje sub-SMAS, se tracciona del colgajo en sentido posterosuperior, hasta mantener una tensión adecuada (Fig. 2). Posteriormente se sutura el SMAS a la zona inferior, media y superior del tejido periauricular (Fig. 3). ${ }^{16}$

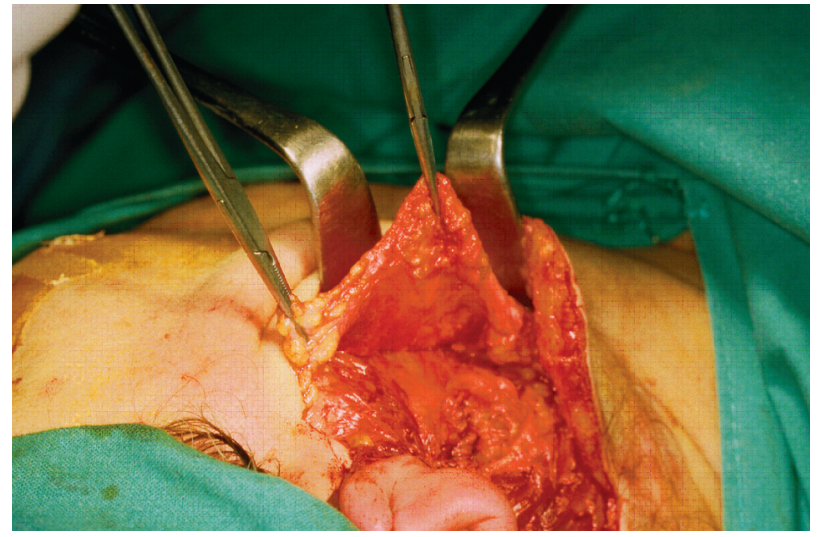

Introduction

Frey's syndrome, also known as auriculotemporal nerve syndrome or gustatory sweating syndrome, is characterized by the appearance of erythema and sweating of the skin on the face, normally in the preauricular region, in relation with mastication and swallowing. It has been observed in patients after suffering a parotidectomy, trigeminal herpes zoster, parotiditis, fractures of the mandibular condyle, obstetric trauma with forceps, and surgery of the meningioma of the cerebellopontine angle. ${ }^{2}$ Incidence after parotid gland surgery is between $30-60 \%{ }^{3}$ It has been described as a late complication that tends to appear 3-6 months after the surgical intervention. ${ }^{3}$

The objective of this article is to analyze if preventing the appearance of Frey's syndrome is possible after the preservation and elevation of a SMAS flap in parotid gland surgery.

\section{Material and method}

A retrospective study has been carried out that includes 81 cases of surgery of the parotid gland carried out by the department of Oral and Maxillofacial Surgery of the Hospital Infanta Cristina, Badajoz, between October 1997 and February 2005.

For the diagnosis of Frey's syndrome, in addition to the clinical symptoms, Minor's test was used. It consists in applying iodine to the skin, letting it dry, adding a layer of starch and offering the patient a sialogogue to stimulate sweating. This will make the starch mix with the iodine and a conclusively dark color will appear.2, 4

The surgical technique of SMAS is the following: After elevating the flap of skin and subcutaneous cellular tissue, the SMAS of parotid fascia is dissected (Fig. 1). The dissection, as we advance along a more anterior plane, has to be very carefully done so that the branches of the facial nerve underlying the fascia are not damaged. The surgical limit is situated a centimeter below the zygomatic arch, and the lower limit 


\section{Resultados}

La mayoría de la cirugía sobre la glándula parótida realizada en nuestro Servicio consistió en parotidectomía superficial conservadora (68\%), seguida en frecuencia por parotidectomía total conservadora (19\%), tumorectomía $(11 \%)$ y parotidectomía total no conservadora (2\%).

Las neoplasias intervenidas en su gran mayoría fueron de histología benigna $(91 \%)$, frente a un $9 \%$ que fueron de histología maligna.

En cuanto a las complicaciones tras cirugía de parótida la más frecuente fue la neuroapraxia del nervio facial (33\%), seguida por la anestesia/parestesia del pabellón auricular (21\%), y en tercer lugar aparece el síndrome de Frey con un total de 13 casos (16\%) (Tabla 1).

De los síndromes de Frey establecidos 6 casos tenían el antecedente de una parotidectomía superficial. En 5 casos se observó que previamente se había realizado una parotidectomía total y 2 surgieron tras una tumorectomía.

Del total de pacientes intervenidos el grupo más numeroso lo forman aquellos pacientes en los que se realizó colgajo de SMAS y no desarrollaron posteriormente

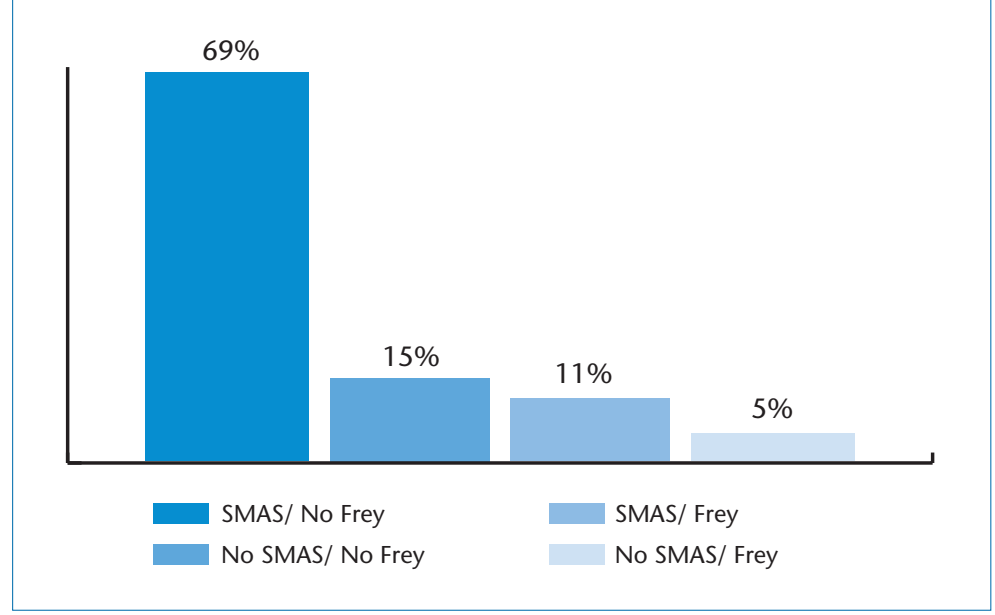

Figura 4. Resultados. Figure 4. Results.

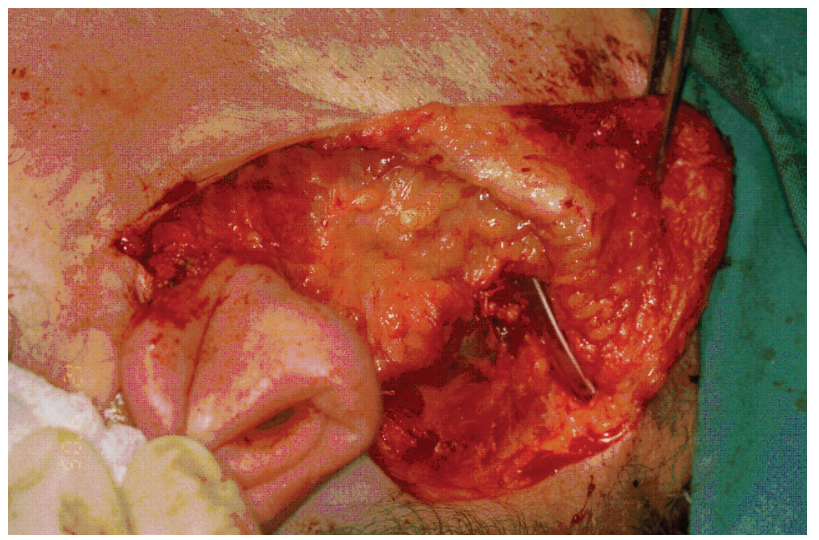

Figura 3. SMAS fijado y colocación del drenaje sub-SMAS.

Figure 3. SMAS in place and placement of the drains under the SMAS. should not be more that a centimeter over the mandibular border. After carrying out the parotidectomy a subSMAS drain is placed, the flap is moved in a postero-superior direction, until there is adequate tension. (Fig. 2) The SMAS is then sutured to the lower, middle and upper area of the preauricular tissue (Fig. 3). ${ }^{16}$

\section{Results}

Most of the surgery on the parotid gland that was carried out by our department consisted of superficial conservative parotidectomies (68\%), followed by, in descending order, total conservative parotidectomies (19\%) tumorectomies (11\%) and non-conservative total parotidectomies (2\%). Most of the neoplasms operated on had 56 casos (69\%). 9 pacientes (11\%) a pesar de realizar colgajo de SMAS sí desarrollaron la sintomatología característica del síndrome. 12 pacientes (15\%) no desarrollaron síndrome de Frey y en ellos no se había realizado colgajo de SMAS. Finalmente en 4 pacientes (5\%) en los que no se había realizado colgajo de SMAS sí se desarrolló el síndrome (Fig. 4).

\section{Discusión}

El síndrome de Frey se caracteriza por la aparición de eritema y sudoración en la piel de la cara en relación con la masticación y la deglución. Se describe como una posible complicación tras cirugía parotídea. La hipótesis más aceptada hoy en día sobre su origen es la regeneración aberrante de fibras parasimpáticas. Dichas fibras acompañan en condiciones normales al nervio auriculotemporal y estimulan la secreción salivar de la glándula parótida. Parece ser que un daño a nivel de dichas fibras provocaría una regeneración aberrante en una dirección inadecuada de las mismas, que alcanzarían y estimularían las glándulas sudoríparas ecrinas de la benign histology (91\%), as opposed to $9 \%$ that were malignant. With regard to complications after parotid surgery, neuroapraxia of the facial nerve was most common (33\%), followed by anesthesia/paresthesia of the outer ear (21\%), and thirdly Frey's syndrome with a total of 13 cases (16\%) (Table 1).

Of the cases in which Frey's syndrome was established, 6 had the antecedent of a superficial parotidectomy. In 5 cases it was observed that a total parotidectomy had previously been carried out, and 2 cases occurred after a tumorectomy.

Of the total number of patients operated on, the most numerous group was made up of patients with raised SMAS flaps who did not later develop Frey's syndrome, with a total of 56 cases (69\%). 9 patients (11\%), in spite of a SMAS flap, did develop the symptomatology that is characteristic of the syndrome. 12 patients (15\%) did not develop Frey's syndrome and they did not have a SMAS flap. Finally, 4 patients (5\%) that had not had a SMAS flap did develop the syndrome. (Fig. 4). 
piel así como los vasos de la dermis, provocando vasodilatación de los mismos.2, 4 Las fibras parasimpáticas implicadas en la fisiopatología del síndrome llevan un recorrido relativamente complejo. Parten del núcleo bulbar salivar inferior. Se incorporan al nervio glosofaríngeo, pasan al nervio de Jacobson, al nervio petroso profundo menor y llegan al ganglio ótico. A partir de ese punto acompañan al nervio auriculotemporal hasta alcanzar la glándula parótida. ${ }^{2}$

Una vez instaurado el síndrome, desde el punto de vista del tratamiento médico y en casos leves se ha utilizado cloruro de aluminio (desodorante roll-on) así como anticolinérgicos aplicados de forma tópica como glucopirrolato, atropina o escopolamina. ${ }^{8}$ Hoy en día ha adquirido gran relevancia el tratamiento mediante toxina botulínica tipo A intradérmica.6, 8

En el caso de precisar tratamiento quirúrgico, una vez que el síndrome de Frey está establecido, hay varias técnicas descritas como la sección del nervio de Jacobson, sección del plexo timpánico, extirpación del nervio auriculotemporal, alcoholización del ganglio cervical superior, ganglio ótico, plexo timpánico, etc. Estas técnicas obtienen resultados estables, pero son excesivamente agresivas en relación con la magnitud del problema. ${ }^{12}$

Por lo tanto, creemos importante hacer hincapié en la prevención de la aparición del síndrome ya que, una vez instaurado, los tratamientos de que disponemos no nos proporcionan resultados totalmente satisfactorios. En el caso de los tratamientos médicos los beneficios son temporales, y desde el punto de vista quirúrgico el obtener resultados estables en el tiempo conlleva el realizar técnicas agresivas, que en la mayoría de los casos, no justifican los síntomas presentados por el paciente.

Para la prevención del desarrollo de Síndrome de Frey tras cirugía a nivel de glándula parótida hay descritas varias técnicas quirúrgicas.9,11,13-15 Una de ellas es la preservación y elevación de un colgajo de Sistema Músculo Aponeurótico Superficial (SMAS). ${ }^{16-22}$ Es una técnica que en manos de un cirujano con experiencia puede prolongar el acto quirúrgico discretamente, ${ }^{16}$ y que a cambio puede evitar las molestias derivadas de la aparición de los síntomas del síndrome de Frey, así como de un tratamiento médico que ha de repetirse de forma periódica o un segundo acto quirúrgico. La utilización del colgajo de SMAS como método de prevención del desarrollo del síndrome de Frey se basa en la aceptación como cierta de la hipótesis de la regeneración aberrante de fibras parasimpáticas anteriormente mencionada. El colgajo se interpone entre el tejido celular subcutáneo y el lecho parotídeo y actúa como barrera que dificultaría la progresión de las fibras parasimpáticas aberrantes hasta la piel.

\section{Discussion}

Frey's syndrome is characterized by the appearance of erythema and sweating of the skin on the face that is related to mastication and swallowing. It is described as a possible complication after parotid surgery. The most accepted hypothesis today as to its origin is that it is an aberrant regeneration of parasympathetic fibers. These fibers in normal conditions accompany the auriculotemporal nerve and they stimulate salivary secretion of the parotid gland. It would seem that damage to these fibers provokes an aberrant regeneration in an inadequate direction, that reaches and stimulates the eccrine sweat glands of the skin as well as the vessels of the dermis, leading to vasodilation.2, 4 The parasympathetic fibers implicated in the physiopathology of the syndrome follow a relatively complex route. They emerge from the inferior salivary bulbar nucleus. They join the glossopharyngeal nerve, pass Jacobson's nerve, the lesser deep petrosal nerve and they reach the otic ganglion. From this point they accompany the auriculotemporal nerve until they reach the parotid gland. ${ }^{2}$

Once the syndrome has started, from the point of view of medical treatment and in minor cases, aluminum chloride (roll-on deodorant) has been used as well as anticholinergic agents such as topical glycopyrrolate, atropine or scopolamine. ${ }^{8}$ Therapy using intradermic botulinum toxin type $A$ is currently growing in importance. 6,8

If surgical treatment is needed, once Frey's syndrome is established, various techniques have been described such as the sectioning of Jacobson's nerve, the sectioning of the tympanic plexus, removal of the auriculotemporal nerve, alcoholization of the superior cervical ganglion, otic ganglion, tympanic plexus... etc. These techniques obtain stable results, but they are excessively aggressive if compared to the magnitude of the problem. ${ }^{12}$

The importance of preventing the syndrome's appearance should be stressed as, once established, the treatment available does not provide totally satisfactory results. With regard to medical treatment, the benefits are temporary, and from the surgical point of view, obtaining stable results will over time entail carrying out aggressive techniques that 
Al analizar los resultados observamos que el grupo más numeroso (69\%) lo forman aquellos pacientes en los que se realizó colgajo de SMAS y no desarrollaron la clínica característica del síndrome de Frey. No obstante, hay un $11 \%$ de los casos en los que a pesar de elevar el colgajo de SMAS, los pacientes presentaron dicho síndrome. Esto podríamos atribuirlo a una técnica incorrecta, a no haber conservado la integridad completa del colgajo o quizá a que en la génesis del proceso patológico influyan otros factores etiológicos que desconocemos y no hemos tenido en cuenta.

Hay que recordar que en cirugía tumoral en que el estudio patológico previo es informado de malignidad no es conveniente preservar el SMAS, así como en casos de tumoraciones benignas íntimamente adheridas al plano del SMAS, ya que se asocia a una mayor tasa de recidivas. ${ }^{16}$

\section{Conclusiones}

Como conclusión aportamos la experiencia en nuestro Servicio y apoyados en la bibliografía existente sobre el tema consideramos adecuada la realización de colgajo de SMAS en cirugía a nivel de glándula parótida, para disminuir la frecuencia de aparición del Síndrome de Frey.

\section{Bibliografía}

1. Frey L. Le Syndrome du nerf auriculotemporal. Rev Neurol 1923;2:97-9.

2. Santa Cruz Ruiz S, Muñoz Herrera A, Santa Cruz Ruiz P, Gil Melcon M, Batuecas Caletrio A. Síndrome de Frey idiopático bajo la apariencia de una otitis externa recidivante. Tratamiento con neuro-toxina botulínica tipo A. Acta Otorrinolaringol Esp 2005;56:83-5.

3. Martín-Granizo R. Manual de Cirugía Oral y Maxilofacial. Ed GlaxoSmithKline 2004;1003.

4. Labarta N, Olaguibel J.M, Gómez B, Lizaso M, García B, Echechipia S, Tabar A. Síndrome de nervio auriculotemporal. Diagnóstico diferencial con alergia alimentaria. Alergol Inmunol Clin 2002;17:223-6.

5. Won-Oak K, Hae-Keum K, Duck- Me Y, Min-Jeong C. Treatment of compensatory gustatory hyperhidrosis with topical glycopyrrolate. Yonsey Medical Journal 2003;44:579-82.

6. Guntinas - Lichius O. Manegement of Frey's syndrome and hypersialorrhea with botulinum toxin. Facial Plast Surg Clin North Am 2003;11:503-13.

7. Laskawi R, Ellies M, Rodel R, Schoenebeck C. Gustatory sweting: Clinical implications and etiologic aspects. J Oral Maxillofac Surg 1999;57:642-8; dicusión 648-9.

8. Kyrmizakis De, Pangalos A, Papadakis CE, Logothetis J, Maroudias NJ, Helidonis ES. The use of botulinum toxin type $A$ in the treatment of Frey and crocodile tears Syndromes. J Oral Maxillofac Surg 2004;62:840-4.

9. Bonanno PC, Palaia D, Rosenberg M, Casson P. Prophylaxis against Frey's syndrome in parotid surgery. Ann Plast Surg 2000;44:498-501.

10. Budzinski R. Frey syndrome: diagnosis and treatment. Otolaryngol Pol 1999; 53:687-91. in most cases are not justified in view of the patient's symptoms.

Various techniques have been described for preventing the development of Frey's syndrome after parotid gland surgery. $.111,13-15$ One is the preservation and raising of a superficial musculoaponeurotic system SMAS flap. ${ }^{16-22}$ If carried out by a surgeon with experience, the surgical act will be extended slightly ${ }^{16}$ and in turn the discomfort that arises when the symptoms of Frey's syndrome appear can be avoided, as well as medical treatment that has to be repeated periodically or a second surgical act. The use of the SMAS flap as a method for preventing the development of Frey's syndrome is based on accepting as correct the previously mentioned hypothesis of aberrant regeneration of parasympathetic fibers. The flap is placed between the subcutaneous cell tissue and the parotid bed and it acts as a barrier that will make the progression of the aberrant parasympathetic fibers towards the skin more difficult.

On analyzing the results, we can see that the most numerous group (69\%) is formed by those patients that had a SMAS flap and that did not develop the characteristic clinical symptoms of Frey's syndrome. Nevertheless, $11 \%$ of cases did develop this syndrome despite the elevation of a SMAS flap. This could be attributed to an incorrect technique if the flap was not completely preserved and intact, or perhaps in the genesis of the pathological process other unknown and influential etiological factors are not being taken into account.

One should remember that in tumor surgery, if the previous pathological study indicates malignancy, the SMAS should not be preserved. This is also the case with benign tumors that are closely attached to the SMAS plane because of an association with a greater recurrence rate. ${ }^{16}$

\section{Conclusions}

In conclusion, given the experience of our department, and supported by the existing literature on the subject, we consider performing surgical SMAS flaps by the parotid gland appropriate, in order to reduce the frequency with which Frey's syndrome appears. 
11. Ahmed OA, Kolhe PS. Prevention of Frey's syndrome and volume deficit after parotidectomy using the superficial temporal artery fascial flap. Br J Plast Surg 1999;52:256-60.

12. Bozzetti A, Biglioli F, Salvato G, Brusati R. Technical refinements in surgical treatment of benign parotid tumours. Journal Cranio-Maxillofacial Surg 1999; 27:289-93.

13. Sood S, Quiraishi M, Jennings C, Bradley P. Frey's syndrome following parotidectomy: prevention using a rotation sternocleidomastoid muscle flap. Clinical Otolaryngology \& Allied Sciencies 1999;24:365.

14. Sinha UK, Saadat D, Doherty CM, Rice DH. Use of Aloderm implant to prevent frey syndrome after parotidectomy. Arch Facial Plast Surg 2003;5:109-12.

15. Dulguerov P, Quinodoz D, Cosendai G, Piletta P, Marchal F, Lehmann W. Prevention of Frey syndrome during parotidectomy. Arch Otolaryngol Head Neck Surg 1999;125:833-9.

16. Falahat F, Martín-Granizo R, Berguer A, De Pedro M, Alonso A, Domínguez L. Empleo del colgajo de sistema músculo-aponeurótico superficial (SMAS) en la cirugía de parótida. Rev Esp Cirug Oral y Maxilofac 2002;24:129-35.
17. Moulton-Barret R, Allison G, Rappaport I.Variaton's in the use of SMAS to prevent Frey's syndrome after parotidectomy. Int Surg 1996;81: 174-6.

18. Belli E, Valentini V, Matteini C. The role of SMAS in the prevention of Frey's syndrome. Minerva Stomatol 1996;45:569-74.

19. Bischofberger A, Linder T, Melik N, Schmid S. Indications an efects of the SMAS in parotid surgery. Schweiz Med Wochenschr 2000; Suppl 125:112S-115S.

20. Angspatt A, Yangyen T, Jindarak S. The role of SMAS flap in preventing Frey's syndrome follow standard superficial parotidectomy. J Med Assoc Thai 2004;87:624-7.

21. Taylor SM, Yoo J. Prospective cohort study comparing subcutaneus and sub-superficial musculoaponeurotic system flaps in superficial parotidectomy. J Otolaryngol 2003;32:71-6.

22. Hoing JF. Facelift approach with a hibrid SMAS rotation advancement flap in parotidectomy for prevention scars and contour deficiency affecting the neck and sweat secretion of the cheek. J Craniofac Surg 2004;15:797-803. 